\title{
KERAJAAN ALLAH DALAM DUA WAJAH Datangnya Ratu Adil dan Kerajaan Allah
}

\author{
Stepanus Istata Raharjo
}

\begin{abstract}
:
The javanese mysticism (Kejawen) reflects a kind of messianic idea of a just king (Ratu Adil) that can be compared to the notion of "God's reign" in Christianity. The concept of "Ratu Adil" had inevitably influenced javanese customs, language system as well as various ritual traditions. Considering that the Kejawen itself is a mixture of various elements from different religious systems (such as Hinduism, Buddhism, and Islam), it is neccessary to trace back sources or traditions, from which the notion of Ratu Adil had been developed. This article aims to discuss and to compare the understanding of "Ratu Adil" with the notion of "God's reign".
\end{abstract}

\section{Kata-Kata Kunci:}

Kerajaan Allah, Ratu Adil, kejawen, tradisi Kristiani.

\section{PENGANTAR}

Kerajaan Allah telah hadir di tengah-tengah kita, tetapi kepenuhannya masih dinantikan. Ia sudah dan sekaligus belum. Ia hadir dalam diri Yesus dengan pewartaan dan karya-karya-Nya namun kepenuhannya tetap dinantikan hari dan saatnya. Itulah sebabnya Kerajaan Allah boleh disebut tampil dalam “dua wajah”. Wajah yang pertama hadir dalam diri Yesus, ketika Ia berkata: "Waktunya telah genap; Kerajaan Allah sudah dekat. Bertobatlah dan percayalah kepada Injil!” (Mrk 1:15). Wajah yang kedua adalah Kerajaan Allah yang tampil secara definitif, yang kepenuhan-Nya masih dinanti di masa mendatang.

"Dua Wajah" juga dimaksudkan bahwa Kerajaan Allah yang dinantikan oleh masyarakat Jawa dengan konsep "Ratu Adil-nya" serta Kerajaan Allah yang dimengerti oleh tradisi kristiani terutama yang tersurat dalam Kitab Suci.

Artikel ini ingin mengeksplorasi bagaimana konsep "Ratu Adil" dalam tradisi Jawa itu disandingkan dan dihadapkan dengan konsep "Kerajaan Allah" dalam tradisi Kristiani. Alur penalaran artikel ini disusun sebagai berikut. Pertama-tama akan dipaparkan konsep "kejawen" yang menjadi latar belakang bagi konsep "Ratu Adil” yang dipahami oleh tradisi Jawa. Selanjutnya menyusul konsep Kerajaan Allah dalam tradisi Kristiani (Kitab Suci). Pada bagian akhir ditampilkan analisis kritis terhadap konsep "Ratu Adil" dan "Kerajaan Allah". Dengan kata lain, artikel ini ditulis dengan menggunakan metode analisis kritis.

\section{KONSEP DAN PANDANGAN HIDUP KEJAWEN}

Masyarakat asli Jawa, sebagaimana masyarakat tradisional lain di dunia, merupakan masyarakat yang gemar sistem mistik. Sepanjang sejarah manusia Jawa, mistik telah mewarnai adat istiadat, bahasa, ilmu pengetahuan dan keagamaan. ${ }^{1}$ Sistem mistik yang sudah menjadi ajaran selama ribuan tahun di pulau Jawa ini dikenal dengan konsep kejawen. Kejawen merupakan suatu konsep hidup yang melingkupi lahir batin-material spiritual. Definisi kejawen dimengerti sebagai suatu kepercayaan tentang pandangan hidup yang diwariskan dari para leluhur. 
Kejawen adalah sebuah kepercayaan yang terutama dianut oleh suku Jawa dan suku bangsa lainnya yang menetap di Jawa. Penanaman kejawen bersifat umum, biasanya karena bahasa pengantar ibadahnya menggunakan bahasa Jawa. Dalam konteks umum, kejawen bukanlah agama. ${ }^{2}$ Penganut ajaran kejawen biasanya tidak menganggap ajarannya sebagai agama dalam pengertian seperti agama monoteistik, seperti Islam atau Kristen, tetapi lebih melihatnya sebagai perangkat cara pandang dan nilai-nilai yang dibarengi dengan sejumlah laku. Ajaran kejawen tidak terpaku pada aturan yang ketat, dan menekankan konsep keselarasan dan keseimbangan lahir batin.

Pandangan hidup orang Jawa atau filsafat Jawa terbentuk dari gabungan alam pikir Jawa tradisional, kepercayaan Hindu atau filsafat India, dan ajaran tasawuf atau mistik Islam. Pandangan hidup tersebut banyak tertuang dalam karyakarya sastra yang berbentuk prosa dan puisi.

Di masa lampau, kejayaan Hindu-Budha begitu terasa dan menggema di Jawa, namun berangsur-angsur menyusut setelah kekuasaan kerajaan Majapahit berakhir dan agama Islam yang berpaham tauhid menyebar. Para wali dan ulama mendominasi pembentukan kharakter religiusitas orang Jawa. Selanjutnya muncul per-campuran antara ajaran agama Islam dengan pemahamanpemahaman kejawen sebelumnya yang sering dikenal dengan nama Islam Kejawen.

\section{KONSEP “RATU ADIL”}

\subsection{Dalam Karya Sastra Jawa}

Konsep dan pandangan tentang "Ratu Adil" tidak lepas dari dua tokoh dalam sejarah kejawen yang melegenda. Tokoh pertama adalah Jayabaya dengan ramalannya yang dikenal dengan "Jangka Jayabaya”. Tokoh kedua adalah Raden Ngabehi Ranggawarsita, seorang pujangga penutup atau pujangga terakhir dalam tradisi kepustakaan Jawa. Kedua tokoh itu hidup pada jaman yang berbeda namun memiliki tali benang merah yang sama dalam kapasitasnya masing-masing.

\subsubsection{Jayabaya}

Prabu Jayabaya dikenal sebagai salah satu panutan penting orang Kejawen. Beliau adalah raja Kediri yang memerintah antara 1135-1157 M yang dikenal sebagai raja yang bijaksana dan memiliki pandangan futuristik. Ia terkenal dengan ramalan tentang keadaan Nusantara di suatu masa di masa datang. ${ }^{3}$
Ramalan Jayabaya itu menyatakan bahwa:

\begin{abstract}
Akan datang satu masa penuh bencana. Gunung-gunung akan meletus, bumi berguncang-guncang, laut dan sungai, akan meluap. Ini akan menjadi masa penuh penderitaan. Masa kesewenang-wenangan dan ketidakpedulian. Masa orang-orang licik berkuasa, dan orang-orang baik akan tertindas. Tetapi, setelah masa yang paling berat itu, akan datang jaman baru, jaman yang penuh kemegahan dan kemuliaan. Zaman Keemasan Nusantara. Dan jaman baru itu akan datang setelah datangnya sang Ratu Adil, atau Satria Piningit.
\end{abstract}

Siapakah Ratu Adil dan Satria Piningit itu? Sebuah pertanyaan yang akan bergulir tiada henti. Namun pokok yang mau disampaikan di sini adalah bahwa sudah sejak zaman prabu Jaya Baya, kerinduan seorang Ratu Adil itu sudah mengemuka.

\subsubsection{R. Ng. Ranggawarsita}

Sedangkan Raden Ngabehi Ranggawarsita hidup pada tahun 1802-1875 M. Ia adalah salah satu pujangga istana Surakarta. Selama hidupnya ia mengabdi lima raja, Sinuwun Paku Buwana V - IX. Loyalitas sang pujangga ini ditunjukkan dengan sejumlah karya-karyanya yang bermutu tinggi. R. Ng. Ranggawarsita termasuk seorang penulis yang peka terhadap permasalahan sosial.

Dalam tradisi kepustakaan Jawa, Ranggawarsita dianggap sebagai pujangga penutup, atau pujangga terakhir. Setelah kematian Ranggawarsita, sudah tidak ada lagi, dan mungkin tidak lagi ada, seorang pujangga. Meskipun sekarang ini masih tetap ada orang-orang yang menulis berbagai karya dalam bahasa Jawa, mereka hanya penulis dan bukan pujangga. ${ }^{4}$ Untuk itulah, penulis memilih Ranggawarsita sebagai pokok pembahasan dalam pemaparan ini, tentu tanpa mengabaikan dan meniadakan pujangga-pujang-ga sebelumnya.

Seorang pujangga, menurut tradisi ini, bukan sekadar penulis, melainkan memiliki kemampuan dan otoritas menangani persoalan-persoalan dunia spiritual. Seorang pujangga memiliki kemampuan menangkap dan memahami tandatanda alam dan tanda-tanda zaman.

Dalam tradisi Jawa, begitu sangat familiar istilah-istilah ini: Ratu Adil, Satria Piningit, Zaman Kalabendhu, Zaman Kalatidha. Bila telah datang Zaman Kalabendhu (zaman edan) hendaklah kita eling lan waspada (sadar dan waspada). Itulah nasihat bijak yang tersurat 
dalam "Serat Kalatidha" yang ditulis oleh pujangga Ronggowarsito IV. ${ }^{5}$

Secara tidak langsung, isilah-istilah itu mengandung makna profetis yang menggambarkan suatu kondisi mengenai zaman yang akan semakin merosot dan suatu harapan mengenai datangnya penyelamat, pembebas yang akan tampil dan memerintah dengan keadilan dan kesejahteraan bagi bumi nusantara ini. Karenanya diperlukan sikap dan perilaku etis dalam menghadapi kehidupan yang keras dan penuh dengan kejahatan agar manusia tidak tersesat. Dalam tradisi Kristiani, pemahaman dan pengharapan masyarakat Jawa ini boleh disetarakan dengan pengharapan mesianis yang selalu dinantikan. Benarkah ada kesetaraan konsep mengenai pengharapan akan masa depan dalam kejawen dan tradisi Kristiani? Bagaimana menjelaskan konsep Ratu Adil dalam tradisi kejawen dan pengertian Kerajaan Allah dalam tradisi Kristiani? Berikut akan dipaparkan terlebih dahulu gagasan R. Ng. Ranggawarsita mengenai Ratu Adil.

Ada lima judul atau tema yang sangat melegenda dalam hasil karya pujangga Ranggawarsita. Pertama, "Zaman Cacat” (judul asli: Kalatid$h a$ ), berisi uraian mengenai kerusakan masyarakat akibat kutukan zaman. Dalam karya ini terdapat frase yang menjadi masyhur, dan akan menjadi pokok uraian dalam bagian ini. Kedua, "Kabar Kepastian” (judul aslinya: Sabda Jati). Dalam bagian ini Ranggawarsita memperingatkan datangnya zaman susah, menuliskan saat kematiannya sendiri, delapan hari sebelum saatnya tiba. Ketiga, "Nasehat Utama" (judul aslinya Sabdatama), di mana sang pujangga memberi nasehat bahwa kesengsaraan yang datang tanpa permisi ini sebenarnya adalah buah perbuatan kita sendiri. Keempat, "Jaka Lodang” yang berkisah tentang ramalan yang dikatakan seorang pemuda, Joko Lodang, tentang kemenangan besar dan datangnya zaman keemasan, di mana para penangguran pun akan menadapt rezeki yang turun bagaikan hujan dari langit. Kelima, "Pedoman Diri” (judul aslinya: Wedha-raga), berisi nasehat, terutama kepada generasi muda, bagaimana menjalani kehidupan sebagai pengabdian, baik kepada Tuhan maupun kemanusiaan, dan bukan panggung pertunjukan untuk mengumbar nafsu. Karya-karya tersebut aslinya berbetuk tembang (nyayian/syair) dengan guru lagu (=persajakan) dan guru wilangan (=jumlah suku kata) yang sistematis. Dan di balik susunan syair atau tembang itu termuat ajaran yang penuh makna padat. Dalam Serat Kalatidha, di mana Ranggawarsita menyebut zaman edan, dapat dilacak konsep Ratu Adil.

Zaman edan atau zaman Kali (Kaliyuga) merupakan sindiran pada kekacauan waktu itu. Kutipan sinom dalam Serat Kalathida menunjukkan kekacauan yang sedang melanda masyarakat: ${ }^{6}$

Amenangi zaman edan (Mengalami jaman gila)

ewuh aya ing pambudi (serba sulit dalam pikiran)

melu edan nora tahan (ikut gila tak tahan)

yen tan melu anglakoni (kalau tidak ikut)

boya keduman melik (tidak dapat bagian)

kaliren wekasanipun (akhirnya kelaparan)

ndilalah karsa Allah (untungnya takdir Allah)

begja-begjane kang lali (seuntung-untungnya orang lupa)

luwih begja kang eling lawan waspada (masih untung yang sadar dan waspada)

Ranggawarsita, melalui Serat Kalatidha tersebut memberi peringatan kepada manusia agar dirinya selalu eling lan waspada, mau mengendalikan diri, tidak terbawa arus sehingga suatu saat dirinya mendapat ketenteraman lahir dan batin. Keadaan masyarakat yang penuh kekacau-an hendaknya diselesaikan dengan arif bijaksana, sehingga tidak malah menambah beban sosial. Di samping itu manusia perlu berserah diri kepada Allah Yang Mahakuasa.

\subsection{Menafsirkan Ratu Adil, Satria Piningit dalam Konteks Indonesia}

Dalam konteks negara Indonesia, pada saat satria piningit muncul, Indonesia sedang menghadapi goro-goro (bhs. Indonesia: kerusuhan besar). Tampilnya satria piningit sebagai pemimpin akan menjadikan bangsa Indonesia akan menuju kemakmuran dan kejayaan seperti pada jaman Kerajaan Sriwijaya dan Majapahit. Ranggawarsita dalam karangannya memaparkan tujuh kriteria pemimpin Indonesia sebagai berikut:

\subsubsection{Satria Kinunjara Murwa Kuncara}

Satria Kinunjara artinya Satria yang terpenjara. Gambaran ini ditafsirkan menunjuk sosok Soekarno yang diketahui keluar masuk penjara sebelum tampil menjadi pemimpin (presiden). Selepas dari penjara ia berhasil melepaskan bangsa Indonesia dari penjara bernama kolonialisme-imperialisme. Ia sangat kuncara (cemer- 
lang) sebagai pemimpin besar yang berhasil mempengaruhi sepertiga dunia dengan gerakan Non Blok yang dibangun dari konsepnya.

\subsubsection{Satria Mukti Wibawa Kesandung Kesam- par}

Satria Mukti Wibawa artinya satria berwibawa. Gambaran ini ditafsirkan menunjuk Soeharto yang diyakini sebagai pemimpin yang berwibawa. Beliau tampil sebagai pemimpin selama 32 tahun tanpa ada orang yang berani melawannya. Namun di akhir kepemimpinannya seolah semua hasil tindakannya kesandhung kesampar (serba buruk dan dipersalahkan semua orang). Bahkan setelah meninggal dunia pun masih dalam status tersangka di muka pengadilan atas tuduhan berbagai skandal korupsi dan kolusi.

\subsubsection{Satria Jinumput Sumela Atur}

Satria Jinumput artinya satria terpungut. Gambaran ini ditafsirkan menujuk salah satu sosok pemimpin bangsa Indonesia, yaitu BJ. Habibie. Ia disebut sumela atur yang berarti menyela kepemimpinan yang sedang lowong setelah ditinggalkan oleh Soeaharto. Terpungut, karena kariernya naik lantaran dipungut dari negeri asing dan menjadi punggawa (pejabat) negeri.

\subsubsection{Satria Lelana Tapa Ngrame}

Satria Lelana artinya satria pengembara. Satria ini ditafsirkan menunjuk sosok Abdurrahman Wahid (Gus Dur) yang pernah menjadi pemimpin bangsa Indonesia. Sejak muda beliau telah menjelajah (berkelana) di sejumlah negara di Asia Selatan, Mesir dan Eropa untuk belajar menempa diri. Ketika menjadi pemimpin pun, beliau rajin berkelana untuk mengunjungi sejumlah negara. Keterbatasan indera mata tidak menjadi halangan dalam pengembaraannya. Beliau juga pantas disebut tapa ngrame (bertapa dan bersemadi dalam keramaian). Hiruk pikuknya dunia tidak membuatnya dia jatuh dan terperangkap di dalamnya.

\subsubsection{Satria Piningit Hamong Tuwuh}

Satria piningit artinya satria yang disembunyikan dan kemudian ke luar dari pertapaannya. Dengan segala kelemahan dan kelebihannya, satria ini diramalkan akan berhasil hamong tumuwuh (merangkul segala komponen) yang ada di bumi nusantara dan mengantarkan ke gapura pembuka jaman keemasan. Apakah ini bisa ditafsirkan menunjuk Megawati? Apakah cocok kalau dikatakan bahwa ia adalah seorang ratu putri yang dipingit dan mendapatkan legitimasi luas karena hamong tuwuh dari ayahandanya, Soekarno. Ia memang menjadi simbol penderitaan selama Orde Baru, sehingga begitu ke luar dari pingitan ia mendapat dukungan luas dari publik. Namun kepemimpinan sekarang penuh dilema. Megawati sebagai pimpinan negara pada akhirnya juga tidak bisa memenuhi dambaan rakyat, bahkan pendukungnya sendiri. Orang Jawa pun susah mengatakan kalau Susilo Bambang Yudoyono adalah Satria Piningit, karena ciri-ciri satria piningit tidak muncul dari dalam dirinya.

\subsubsection{Satriya Boyong Pambukaning Gapura}

Satriya Boyong Pambukaning Gapura berarti satria yang berpindah tempat dan membuka gerbang. Pemimpin yang akan menjembatani ke arah kemakmuran. Ia adalah negarawan tanpa pamrih. Ia mengemban tugas meletakkan fondasi kenegaraan seperti membuka pintu gapura jaman keemasan dan menggelar tikar, walau pun tidak akan sempat nglungguhi klasa gumelar (duduk di atas tikar yang sudah terbentang).

\subsubsection{Satria Pinandita Sinisihan Wahyu}

Satria Pinandita Sinisihan Wahyu artinya Satria yang berjiwa dan bersemangat religius yang kuat. Dialah pemimpin yang ditunggu yang akan membawa kepada kemakmuran dan kesejatian bangsa. Dialah Ratu Adil yang dinantikan kehadirannya di tengah-tengah bangsa yang sedang terpuruk secara moral dan ekonomi saat ini. Akankah sudah dekat masanya Sang Satria Pinandita Sinisihan Wahyu datang menjadi mesiasnya orang Jawa? Sebuah pertanyaan yang menjadi penantian terus-menerus.

\subsection{Ratu Adil: Sebuah Angan-Angan?}

Istilah "Ratu Adil" muncul dala "Jangka Jayabaya" atau ramalan Jayabaya, sedangkan "Jaman Edan" dan "eling lan waspada" muncul dalam Serat Kalatidha karya Pujangga Ranggawarsita. Berbagai pengamat kebudayaan dan penganut kejawen saling berbeda pendapat mengenai siapa tokoh Ratu Adil serta kapan peristiwa "Zaman Edan” itu terjadi. Dari sebutannya, Ratu Adil dapat ditafsirkan sebagai seorang yang mampu menempatkan sesuatu pada tempatnya. Ratu Adil juga pasti mampu menjadi pelindung atau pengayom dari seluruh rakyat, tanpa membedakan golongan, tanpa keberpihakan kecuali hanya berpihak kepada kebenaran hakiki yang bersifat universal. Dengan ciri ini maka sulitlah kiranya jika Ratu Adil ini berasal 
dari salah satu kelompok kepentingan yang dibesarkan oleh kelompok kepentingan itu.

Itulah sosok Ratu Adil yang sampai saat ini hanya ada di dalam angan-angan. Selama sosok Ratu Adil itu hanya ada di dalam angan-angan, selama itu pulalah keadilan, kemakmuraan, ketentramaan, serta kesejahteraan hidup hakiki yang selalu didambakan itu juga hanya ada di dalam angan-angan, atau bahkan hanya ada di dalam alam impian di atas impian di dalam lamunan belaka.

Mungkinkah undang-undang atau tatanan politik kita mampu memunculkan sosok Ratu Adil? Berbagai penjelasan di atas, membawa kita pada suatu kesimpulan bahwa jatidiri sosok Ratu Adil itu masih diperdebatkan, mengingat berbagai tokoh yang pernah diduga sebagai Ratu Adil, justru sekarang dianggap membawa keterpurukan bangsa. Pernyataan itu menyiratkan suatu pengharapan eskatologis yang akan segera mendapatkan penggenapannya. Pun demikian, pengharapan itu tidak serta merta dapat diterapkan dan teralisir dalam konteks sosial-politik seperti sekarang ini. Adapun Zaman Edan, merupakan suatu fenomena tetap akan terjadi dalam konteks hidup kita. Dalam konteks hidup sekarang ini penggambaran tentang Zaman Edan itu terasa sangat kontekstual, ketika kita melihat dan mengalami kondisi bangsa yang sedang mengalami berbagai krisis multidimensional serta berbagai bencana yang melanda.

\section{KERAJAAN ALLAH}

Kedatangan Kerajaan Allah adalah fokus perutusan Yesus. "Sesudah Yohanes ditangkap, datanglah Yesus ke Galilea memberitakan Injil Allah, kata-Nya: Waktunya telah genap; Kerajaan Allah sudah dekat. Bertobatlah dan percayalah kepada Injil” (Mrk 1:14-15). Bahkan Kerajaan Allah itu seakan menjadi tujuan akhir pengharapan Kristen. ${ }^{7}$ Pertanyaanya adalah bagaimana konsep Kerajaan Allah itu dimengerti? Untuk mendapatkan gambaran yang kurang lebih komprehensif, akan dipaparkan paham 'Kerajaan Allah' itu dalam Perjanjian Lama dan pada akhirnya dalam Perjanjian Baru yang menemukan klimaksnya dalam diri Yesus, sang Pewarta dan Pemaklum Kerajaan Allah. ${ }^{8}$

Pada waktu Israel berkembang sebagai umat, satu-satunya sistem pemerintahan yang ada ialah kerajaan. Karenanya, menggambarkan kuasa Allah dipakai gambaran raja. Bagi Israel, Allah satu-satunya raja. Kalau pun bangsa Israel pernah hidup dalam zaman kerajaan, kekuasaan se- sungguhnya terletak dalam diri Allah yang menjadi raja atas umat. Raja-raja yang memerintah bangsa Israel adalah wakil Allah di dunia. Keyakinan ini semakin menguat ketika kerajaan duniawi mereka runtuh, pada saat Israel mengalami kehancuran. Dalam pembuangan di Babilonia, Yesaya menubuatkan bahwa akhirnya Allah akan menyatakan diri-Nya sebagai raja (Yes 40-55).

Harapan mesianis yang selanjutnya berkembang memperdalam gagasan ini. Digambarkan, Allah akan menegakkan kerajaan-Nya dengan perantaraan utusan-Nya, yaitu sang Mesias. Mesias sering kali digambarkan sebagai anak Daud, gembala Israel (2 Sam 7; Yeh 34; Zak 9-14; Mzm 2). Sastra apokaliptik dengan gambaran Anak Manusia pada Kitab Daniel 7, menunjukkan unsur yang lain lagi: kerajaan ini bersifat universal dan berhubungan dengan akhir zaman.

Raja mempunyai dua fungsi utama, dan dengan demikian juga Allah Raja. Pertama, raja mesti menjamin kemerdekaan umat-Nya: Ia adalah komandan perang yang menghancurkan musuh-musuh. Pada zaman Yesus keyakinan ini tampak berkembang dalam beberapa kelompok Yahudi yang berharap bahwa dengan menegakkan kerajaan-Nya Allah akan membebaskan Israel dari penjajahan Romawi (Luk 24:21). Jelas Yesus tidak pernah mengambil alih gagasan ini. Kedua, raja yang sejati mesti juga menjadi keadilan di antara umat. Lebih-lebih ia adalah raja bagi orang-orang miskin, tertindas dan orang-orang yang tidak mempunyai suara. Yesaya memaklumkan Injil ini: Allah meraja! Terberkatilah yang miskin, sakit dan tertindas, karena kemalangan mereka akan berakhir. Ini juga merupakan kabar baik yang diwartakan oleh Yesus. Ia memaklumkannya dengan tindakan dan dengan kata-kata.

Pertanyaannya adalah bagaimana konsep dan pengertian mengenai Kerajaan Allah itu berkembang dari waktu ke waktu? Kita akan menelusuri 'gerak' Kerajaan Allah itu secara lebih khusus dalam Perjanjian Lama dan Perjanjian Baru yang memuncak pada pewartaan Yesus.

\subsection{Dalam Perjanjian Lama}

Gagasan tentang Kerajaan Allah berasal dari tradisi Israel. Tradisi itu berpangkal pada pengalaman sejarah pembebasan umat Israel dari penindasan Mesir. Pengalaman itu membentuk iman Israel bahwa Allah adalah Tuhan atas sejarah. Setelah melalui Perjanjian Sinai, bangsa Israel menjadi bangsa terpilih, bangsa dengan sebuah masa depan dan harapan. Perjanjian Sinai 
menuntun pada pemahaman bahwa Tuhan atas sejarah adalah benar-benar sang Pencipta alam semesta. Tuhan adalah Raja atas seluruh dunia yang diciptakannya, sebagaimana terlukis dalam Mazmur 24:1.10:

Tuhanlah yang empunya bumi serta segala isinya, dan dunia serta yang diam di dalamnya.Siapakah Dia itu Raja kemuliaan? Tuhan semesta Alam. Dialah Raja Kemuliaan!

Harapan bangsa Israel akan Allah sebagai raja, dari waktu ke waktu mengalami perkembangan. Harapan akan keselamatan itu bukan sesuatu yang 'abstrak' atau pada setelah manusia meninggalkan dunia. Keselamatan diharapkan menjadi nyata dalam dunia, yaitu suatu bangsa yang mengalami rasa aman dan damai. Ketika Allah meraja, ada keadilan. Bila ada keadilan akan ada rasa aman, damai dan kemakmuran.

Dalam perkembangan selanjutnya keyakinan Allah sebagai Raja menampak dalam diri tokohtokoh. Pertama-tama para pemimpin mereka adalah para hakim, yaitu orang yang dipanggil pada saat krisis untuk menjalankan peran tertentu. Para hakim mereka yakini sebagai wakil Allah. Setelah era para hakim, diangkatlah Raja atas kehendak bangsa Israel pada waktu itu. Hal itu tidak lepas dari keinginan bangsa Israel untuk memiliki seorang pemimpin atau raja yang bisa menjadi pemersatu umat sebagai benteng pertahanan dari serangan musuh. Samuel, salah seorang hakim di Israel yang mendapatkan tugas untuk memilih dan mentahbiskan Saul sebagai raja pertama. Dan mulailah jaman kerajaan Israel dengan tidak boleh mengesampingkan Raja Daud sebagai satu-satunya Raja Israel yang paling besar dan melegenda. Namun di balik itu semua, bangsa Israel percaya bahwa raja sesungguhnya adalah Allah. Pemazmur menggambarkannya sebagai berikut:

Hai segala bangsa bertepuktanganlah, eluelukanlah Allah dengan sorak sorai! Sebab Tuhan, Yang Mahatinggi, adalah dahsyat. Raja yang besar atas seluruh bumi. Ia menaklukkan bangsa-bangsa ke bawah kuasa kita,Suku-suku bangsa di bawah kaki kita (Mzm 47:1-3)

Dalam perkembangannya, umat Israel sampai pada keyakinan akan pemenuhan di zaman akhir, ketika menyaksikan dan mengalami aneka macam perjuangan dan bahkan penderitaan, terutama ketika ada dalam pembuangan. Atas peran dan pewartaan para nabi (di masa pembuangan) umat israel dibawa menuju kepada pengharapan akan kepenuhan di masa nanti. Itulah sebabnya iman bangsa Israel memiliki dimensi eskatologis. Otto Hentz, SJ, dalam bukunya "Pengharapan Kristen” membagi iman eskatologis itu memiliki dua fase, yaitu: eskatologi profetis (kenabian) dan eskatologis apokaliptik (wahyu). ${ }^{9}$

Eskatologik profetik bukanlah ramalan tentang masa depan dengan bola kristal tetapi sesuatu yang terkait dengan realisme politis. Karena Allah menanamkan kuasan-Nya melalui tindakan dalam sejarah manusia, maka para nabi menafsirkan sejarah, menafsirkan kehendak Allah bagi umatnya, dan menerangkan harapan akan pemenuhan masa depan.

\subsubsection{Eskatologi Profetik}

Eskatologi profetik berkembang dalam tiga tahap. Tahap pertama, harapan tampak pada wangsa Daud. Allah memberdayakan raja, yang disebut sebagai “anak-Ku” (Mzm. 2:7). Para nabi menekankan kuasa dan pengaruh Allah. Raja bertindak menurut sarana belas kasih Allah, bertindak adil dan memperhatikan kaum msikin. Melalui Daud, Allah membangun kerajaan kekal. Namun faktanya, kerajaan Israel terbagi. Kerajaan utara (Israel) ditaklukkan Asyur dan Kerajaan Selatan (Yehuda) jatuh dalam kekuasaan Babel. Dan para nabi menginterpretasikan bencana ini sebagai penghakiman atas ketidaktaatan bangsa Israel terhadap perjanjian.

Setelah kejatuan dinasti Daud, dimulailah tahap kedua, yakni harapan yang tampak pada adanya pembaruan masa depan dari wangsa Daud. Allah akan mengangkat seorang raja yang akan membangun kerajaan yang besar, aman dan makmur.

Seorang anak akan lahir untuk kita, seorang putra telah diberikan untuk kita:...besar kuasaNya dan damai sejahtera tidak akan berkesudahan, Di atas tahta Daud, dan di dalam kerajaannya, karena ia mendasarkan dan mengokohkannya Dengan keadilan dan kebenaran dari sekarang sampai selamalamanya (Yes. 9:5-6)

Pada tahap kedua ini para nabi menghadirkan sebuah harapan yang religius dan lingkupnya lebih universal. Keselamatan berarti terciptanya Israel baru melalui pemberian semangat baru untuk menjawab kehendak Allah (Yer 31:31). Namun ketika wangsa Daud tidak kunjung datang, harapan akan keselamatan memasuki tahap ketiga, yaitu Allah akan campur tangan dan secara pasti akan membangun pemerintahan atau kerajaan Allah di dunia. Seorang penguasa manusia yang dicita-citakan akan menjadi alat Tuhan 
dalam suatu pembaruan bangsa yang mulia dan terakhir. Tuhan akan memberikan kemakmuran dan kedamaian kepada semua orang yang mengakui pemerintahan-Nya dan hidup sesuai dengan kehendak-Nya. Tuhan akan membangun langit dan bumi yang baru dengan ciptaan yang hidup selaras dan damai.

Ia akan meniadakan maut untuk seterusnya; dan Tuhan ALLAH akan menghapuskan air mata dari pada segala muka; dan aib umatNya akan dijauhkan-Nya dari seluruh bumi, sebab TUHAN telah mengatakannya. (Yes. 25:8)

\subsubsection{Eskatologi Apokaliptik}

Apokaliptik menggambarkan kedatangan pemerintahan/kerajaan Allah sebagai intervensi dramatik dari bagian kosmik di mana perjuangan historis antara baik dan buruk mencapai puncaknya. Tuhan secara pasti menghancurkan kuasa kejahatan, mengakhiri dosa dan kematian, dan membangun kerajaan yang tidak berkesudahan. Jika dalam eskatologi profetik memimpikan pemerintahan Allah yang universal, melihat ke masa depan Israel di dunia, Eskatologi apokaliptik mengharapkan pemenuhan masa depan dalam wilayah transendental yang dibangun oleh kedaulatan Tuhan yang kuasa-Nya mengatasi hidup dan kematian. Usaha manusiawi, institusi manusiawi hanya menghasilkan kegagalan dan tragedi. Allah adalah satu-satunya harapan. Maka, yang dikemukakan apokaliptik sebagai tujuan pengharapan bukan pembaruan bangsa Israel, tetapi masa depan di luar sejarah manusia. Apa yang dipertaruhkan bukan nasib individu atau nasib bangsa, melainkan seluruh ciptaan.

Singkat kata, perkembangan pemahaman gagasan tentang Kerajaan Allah melalui eskatologi profetik dan apokaliptik menentukan tahapan pengajaran Yesus. Berbicara tentang Kerajaan Allah berarti berbicara tentang kedaulatan Allah. Allah menciptakan dan mempertahankan dania, bertindak dalam sejarah untuk menyelamatkan Israel, dan akan, pada akhirnya, membangun pemerintahan yang aman atas seluruh dunia.

\subsection{Dalam Perjanjian Baru}

Harapan Israel akan datangnya seseorang yang akan memaklumkan Kerajaan Allah terpenuhi dalam diri Yesus. Semua Injil memperkenalkan Yesus sebagai Mesias (bhs. Yunani: Kristus), orang yang terurapi dari keturunan Daud.

Kedatangan Kerajaan Allah merupakan bentuk khusus dari karya penyelamatan Allah yang diwartakan oleh Yesus. Keempat Injil, dengan cara dan bahasanya masing-masing memberitakan datang-Nya Kerajaan Allah melalui dan dalam diri Yesus.

Yesus mengajarkan tentang Kerajaan Allah kepada para murid-Nya melalui perumpamaan. Kadang Kerajaan Allah diumpamakan seperti biji sesawi, kadan Kerajaan Allah diumpamakan seperti pencuri yang datang dengan tiba-tiba. Namun kisah-kisah-Nya mengungkapkan bahwa Allah adalah kasih yang berbela rasa, murah hati dan pengampun.

Dalam menyatakan kedatangan Kerajaan Allah, Injil tetap mempertahankan ketegangan antara masa sekarang dan masa datang. Kerajaan Allah adalah realitas sekarang karena Allah bertindak secara nyata dalam diri Yesus. Kerajaan Allah adalah realitas masa datang karena kerajaan yang dimaklumkan Yesus hanya akan terwujud sepenuhnya pada akhir zaman.

Dalam bab-bab awal Injil Markus, digambarkan tindakan kedaulatan Allah dalam diri Yesus dengan serangkaian karya-karya mukjizat (penyembuhan orang saki). Sedangkan dalam Lukas, Yesus mengawali karyanya dengan mengutip nubuat Nabi Yesaya, sebagaimana tersurat dalam Lukas 4:18-19:

Roh Tuhan ada pada-Ku, oleh sebab Ia telah mengurapi Aku, untuk menyampaikan kabar baik kepada orang-orang miskin;dan Ia telah mengutus Aku untuk memberitakan pembebasan kepada orang-orang tawanan, dan penglihatan bagi oang-orang buta, untuk membebaskan orang-orang yang tertindas, untuk memberitakan tahun rahmat Tuhan telah datang. (Luk 4:18-19).

Ia kemudian menyatakan, "Pada hari ini genaplah nas ini sewaktu kamu mendengarnya" (Luk 4:21). Secara eksplisit Yesus menghubungkan tampilnya Kerajaan Allah dengan pelayananNya, "Tetapi jika Aku mengusir setan dengan kuasa Allah, maka sesungguhnya Kerajaan Allah sudah datang kepadamu” (Luk 11:20). Zaman baru telah dimulai sekarang ini.

Tetapi pada saat yang sama, kepenuhan Kerajaan Allah berada di masa datang. Yesus mengajar para murid-Nya untuk berdoa mengharapkan kedatangan Allah (Luk 11:2). Banyak perikop mengenai penghakiman menunjuk pada kedatangan Kerajaan Allah di masa mendatang, seperti misalnya: Mat 13:24-30, 36-43.

Dengan demikian pengharapan akan datangnya Kerajaan Allah memiliki berbagai dimensi. 
Awalnya pengaharapn akan kerajaan masa datang akan segera datang, seperti tergambar dalam kisah-kisab berikut: nasehat untuk berjaga-jaga (Mat 25:1-13); Tawaran keselamatan yang menuntut pertobatan radikan dan tanpa syarat (Mat 10:32-33); dan bila gagal menanggapi tawaran itu akan membawa penghukuman (Mat 13:47-50).

Di sisi lain, dinamika Kerajaan Allah telah berpengaruh pada saat sekarang, seperti ragi tanpa gandum (Mat 13:33) atau biji yang jatuh ke tanah (Mrk 4:3-9). Kerajaan Allah bekerja secara efektif, meski tidak kentara. Sebagai jawaban atas pertanyaan tentang kedatangan Kerajaan Allah, Yesus menyatakan, "Kerajaan Allah ada di antara kamu” (Luk 17:21). Di sisi lain, Yesus meminta para murid-Nya untuk berdoa agar Kerajaan Allah datang (Mat 6:10), meskipun tentang hari dan saatnya, "tidak seorang pun yang mengetahuinya, malaikat-malaikat di surga tidak, dan Anak pun tidak, hanya Bapa sendiri” (Mat 24:36).

Sebagaimana telah dilihat, pada masa sebelum misi Yesus, umat Israel mengharapkan campur tangan Allah secara nyata. Beberapa orang mencari surga dan bumi baru dalam realitas transendental, yang lain mengakui Kerajaan Allah yang memiliki dua dimensi: kerajaan surgawi, yang sudah dibangun dan dari sanalah Allah memerintah atas sejarah di bumi; dan kerajaan duniawi, yang belum datang, di mana raja yang dicita-citakan memerintah Israel dan bangsabangsa dengan bijaksana.

Tampak bahwa selama kehadiran Yesus, pengharapan yang berkembang adalah pengharapan akan pemenuhan Kerajaan Allah di dunia yang dimaklumkan oleh Yesus, meskipun tidak ada definisi yang tepat atas bentuk atau saat pemenuhannya. Namun keyakinan para murid pada waktu itu adalah Kerajaan Allah sedang hadir dalam diri Yesus. Walau pun pada akhirnya para murid menjadi kecewa dan hilang harapan ketika Yesus yang diyakini sebagai pemenuhan harapan akan keselamatan Allah itu wafat di salib (Luk 24:21). Kemudian setelah kebangkitan-Nya, harapan akan Kerajaan Allah bangkit kembali dalam bentuk harapan akan kedatangan Kristus yang kedua. Untuk sebagian orang, kedatang kedua bisa berarti bahwa Yesus akan memerintah bumi. Akan tetapi, harapan akan nasib transenden di luar sejarah menentukan konteks untuk menerima dan mengartikan makna kebangkitan Yesus. Kebangkitan Yesus mengungkapkan makna Kerajaan Allah secara penuh: hidup kekal dalam persekutan dengan Allah.
Dengan demikian umat Kristen mengalihkan harapan kedamaian dan kemakmuran orang Yahudi menjadi harapan akan Kerajaan Allah di surga. Kepenuhan akan keselamatan itu diletakkan pada sebuah harapan bahwa Kerajaan Allah akan dikukuhkan Yesus dan dibangun kembali yang kepenuhannya akan dicapai di surga. Namun lagi-lagi tetap harus memegang keyakinan ini, "Tetapi tentang hari dan saat itu tidak seorang pun yang tahu,....hanya Bapa sendiri” (Mat 24:36).

Dalam Perjanjian baru secara terangbenderang nampak ada ketegangan pada saat membicarakan datangnya Kerajaan Allah. Ketegangan itu muncul karena Kerajaan Allah telah datang bersama Yesus, tetapi belum mencapai kepenuhannya, baik saat kebangkitan Yesus mau pun segera setelahnya.

\subsubsection{Kerajaan Allah yang Selalu Dinantikan $^{10}$}

Rumusan yang ada dalam doa Bapa Kami, "Datanglah Kerajaan-Mu"" mengungkapkan harapan serta kerinduan yang paling dalam dari masyarakat pada waktu itu, bahkan setiap manusia, untuk mengembangkan kehidupan bersama yang bersaudara dan adil. Dalam bagian doa itu pula dapat ditemukan rangkuman seluruh pewartaan dan inti perutusan Yesus. Inti dari perutusan Yesus adalah mewartakan Kerajaan Allah. Bagaimana Kerajaan Allah itu diwartakan oleh Yesus?

\subsubsection{Pewartaan Yesus tidak Bertujuan Politis-Praktis}

Penilaian salah orang kebanyakan pada waktu itu adalah melihat pewartaan Yesus dikaitkan dengan politik praktis. Dari satu pihak, orang banyak memandang Yesus sebagai utusan yang dipilih Allah untuk membebaskan Israel dari penjajah asing. Dari lain pihak, para penguasa wilayah maupun pemimpin bangsa di Yerusalem rupanya khawatir, jangan-jangan yang Ia ajarkan dan lakukan dapat mendorong gerakan untuk mengubah tatanan masyarakat yang ada.

Meskipun demikian, seluruh penampilanNya, pewartaan sabda dan karya-Nya tidak mempunyai tujuan politis langsung, sebagaimana yang diperjuangkan oleh kaum Zelot. Yesus mengharapkan datangnya Kerajaan Allah dalam waktu yang dekat dan mewartakannya. Maka segala hal yang berbau duniawi (termasuk di dalamnya politk) tidak menjadi pusat 
perhatiannya (bdk. Mrk. 12:13-17; Mat 17:25 dst).

\subsubsection{Yesus Mengharapkan Kedatangan Kerajaan Allah dalam Waktu Dekat}

Injil Sinoptik mengisahkan tokoh Yohanes Pembaptis yang mendahului Yesus dalam pewartaan Kerajaan Allah itu. Sinoptik juga mengisahkan peran Yohanes sebagai yang membaptis Yesus. Kita tahu bahwa warta baptis Yohanes adalah demi pengampunan dosa, dalam rangka menyiapkan kedatangan Kerajaan Allah dalam waktu dekat. .Dengan demikian dapat disimpulkan bahwa Yesus memulai karya-Nya dengan menerima baptisan dari orang yang mengharapkan Allah akan menegakkan Kerajaan-Nya dalam waktu dekat.

Paulus sebagaimana tampak dalam surat yang ia tulis pada awal karya pewartaannya, ${ }^{12}$ juga mengharapkan kedatangan Kerajaan Allah dalam waktu yang dekat. Ia mengatakan kepada orang-orang Tesalonika bahwa mereka masih akan hidup pada waktu Tuhan datang kembali. Ketika ternyata beberapa dari antara mereka meninggal, orang-orang yang masih hidup bertanya-tanya mengenai nasib mereka yang sudah meninggal. Paulus menjawab pertanyaan itu dengan mengutip "Sabda Tuhan" yang menyatakan bahwa baik orang Kristiani yang sudah mati maupun yang masih hidup akan "diangkat bersama-sama dalam awan menyongsong Tuhan di angkasa” (1 Tes 4:17). ${ }^{13}$ Harapan seperti itu masih tampak dalam surat-surat yang lebih kemudian. Ketika berada di penjaran, Paulus berpikir tidak akan hidup lagi pada saat Tuhan datang kembali (Flp. 1:22 dst), namun ia tetap mengharapkan kedatangan-Nya (Flp 3:20 dst. Bdk. Rm. 13:11-14).

Ketika Yohanes Pembaptis yang mendahuluiNya dalam pewartaan Kerajaan Allah dan Paulus yang menyusul-Nya mempunyai harapan yang sama, sulit dibayangkan kalau Yesus yang ada di antaranya tidak mempunyai harapan yang sama. Kesimpulan ini diperkuat oleh sabda yang serupa dengan yang terdapat dalam 1 Tes 4:13-18: “Aku berkata kepadamu, sesungguhnya di antara orang yang hadir di sini ada yang tidak akan mati sebelum mereka melihat bahwa Kerajaan Allah telah datang dengan kuasa” (Mrk. 9:1; bdk. Mat 16:27-28; 24:31).

Dengan demikan tampak jelas bahwa Yesus mengharapkan datangnya Kerajaan Allah dalam waktu dekat. Soal akan menjadi lain kalau ditanyakan apakah yang sebenarnya dipikirkan oleh Yesus mengenai Kerajaan Allah itu? Jawaban atas pertanyaan ini harus dicari dengan menafsirkan sabda-sabda tentang Kerajaan Allah yang terdapat dalam Injil, yang mungkin sudah diredaksi oleh para penginjil.

\subsubsection{Kerajaan Allah dalam Sintesa}

Pada akhirnya sintesa dari konsep Kearjaan Allah itu bisa kita rumuskan sebagai berikut:

a. Kerajaan Allah adalah realitas transenden, yang dimasuki oleh orang satu demi satu. Realitas transenden itu berupa kekuasaan atau pemerintahan yang dapat diterima atau diakui oleh seseorang. Pengakuan itu mensyaratkan masuknya orang ke dalamnya. "Bukan setiap orang yang berseru kepada-Ku: Tuhan, Tuhan! akan masuk ke dalam Kerajaan Sorga, melainkan dia yang melakukan kehendak Bapa-Ku yang di sorga" (Mat 7:21).

b. Kerajaan adalah realitas masa depan yang akan datang. Tidak dijelaskan bagaimana datangnya, seperti apa wujudnya.

c. Kerajaan akan ditegakkan oleh para Malaikat Allah atau oleh Anak Manusia. Kedatangannya akan disertai oleh tandatanda kosmis. Teks-teks yang memuat gagasan ini tidak menyebut kata "kerajaan", tetapi yang menjadi pokoknya adalah penegakan kerajaan. Tidak jelas bagaimana tokoh akhir zaman itu disebut Anak Manusia. Lebih tidak jelas lagi pandangan Yesus sendiri tentang hubungan diri-Nya dengan Anak Manusia -dengan pengandaian Ia memang menubuatkan kedatangan Anak Manusia (bdk. Mrk 8:38-9:1).

d. Kerajaan itu hadir dalam sabda dan karya Yesus. "Atas pertanyaan orang-orang Farisi, apabila Kerajaan Allah akan datang, Yesus menjawab, kata-Nya: "Kerajaan Allah datang tanpa tanda-tanda lahiriah, juga orang tidak dapat mengatakan: Lihat, ia ada di sini atau ia ada di sana! Sebab sesungguhnya Kerajaan Allah ada di antara kamu." (Luk 17:20-21) ${ }^{14}$

Dari pemaparan itu nampak bahwa dalam karya-Nya, kerajaan Allah sudah tampak dalam "antisipasi”; Kerajaan Allah itu akan datang di masa depan, disertai tanda-tanda kosmis dan penampakan Anak Manusia dengan Malaikat; Ia dan murid-murid akan mempunyai tempat penting di dalamnya; komitmen pribadi akan menentukan seseorang masuk atau tidak masuk kalau Kerajaan Allah datang; sekarang orang dapat masuk, dalam arti menerima pemerintahan 
Allah dalam hidup mereka dan dengan hidup sesuai dengan Roh-Nya. Dengan demikian orang dituntut untuk menghayati hidup sebagai anakanak Allah bukan pertama-tama dengan berseru "Tuhan, Tuhan, tetapi dengan melaksanakan kehendak-Nya” (bdk. Mat 7:21).

\section{CATATAN REFLEKTIF: DUA WA- JAH KERAJAAN ALLAH DAN PE- NANTIAN "RATU ADIL"}

Sebagaimana sudah dipaparkan mulai dari pengantar maupun isi tulisan ini, nampak bahwa Kerajaan Allah adalah sebuah realitas yang sudah dan belum. "Dua Wajah” Kerajaan Allah itu adalah: realitasnya sungguh nyata dan sudah ada. Ia hadir dalam diri Yesus Kristus yang dinyatakan sebagai pewarta, pemaklum dan pewujud Kerajaan Allah itu sendiri. Kehadiran-Nya, karya serat mujizat-mujizat-Nya memperlihatkan bahwa Kerajaan Allah itu ada di tengah-tengah umat, menyentuh dan menembus setiap hati yang percaya kepada-Nya. Karya-karya penyembuhan dan tanda-tanda heran lainnya memperlihatkan bahwa Allah sungguh meraja: membawa pembebasan, penyembuhan, penghidupan bagi orang yang telah mati -dalam hati sebenarnya- maupun yang telah 'mati' karena disingkirkan, dikucilkan oleh sesamanya. Yesus hadir menghidupkan kembali orang yang telah diasingkan dan dibuang karena dinilai 'najis' oleh sebab penyakit kustanya. Ia pun 'menghidupkan kembali' se-orang kepala pemungut cukai yang menjadi musuh masyarakat karena tindak tidak adilnya. Kehadiran Yesus menjadikan si pemungut cukai itu memperoleh hidup baru dengan pertobatannya. Demikian juga terhadap wanita yang sedang kedapatan berbuat zinah, Yesus pun memberikan harapan dan kehidupan baru dengan pengampunannya. Tentu, karya dan mujizat-mujizat Yesus tidak dapat diurai satu persatu. Namun semua itu memperlihatkan betapa "Kerajaan Allah" itu sungguh nyata dan dialami dunia.

Karya "Kerajaan Allah" itu terenyata belum mendapatkan kepenuhannya. Kepenuhan karya keselamatan Allah itu akan diterima oleh manusia pada saat kedatangan-Nya yang kedua. Pada saat itulah manusia yang percaya kepada-Nya akan mengalami keselamatan secara penuh, dengan tetap menyertakan prasyarat bagi manusia. Yang setia sampai pada akhirnya akan mendapatkan keselamatan. Dengan demikian setiap orang beriman tertantang untuk mengusahakan hidup baik dan memperjuangkan keutamaan agar mendapatkan kemuliaan pada akhirnya, ketika manusia meninggalkan dunia ini. Harapan akan datangnya Kerajaan Allah itu bukanlah harapan kosong karena orang beriman menyandarkan harapannya pada Yesus yang akan datang untuk kedua kalinya pada akhir zaman, akhir hidup kita masing-masing. Harapan itu memiliki dimensi kepastiannya.

Sedangkan "Ratu Adil" yang dinantikan dalam tradisi Kejawen tidak memiliki dimensi keilahian. "Ratu Adil” yang telah diramalkan selalu menunjuk pada pribadi manusia, bukan Yang Ilahi. Sudah sejak dahulu orang Jawa menjadikan "Jayabaya" dalam jajaran ratu adil itu. Dalam perkembangan selanjutnya "Ratu Adil" diramalkan hadir pada diri para pemimpin, mulai Soekarno, Soeharto, dan para pemimpin-pemimpin selanjutnya. Faktanya "Ratu Adil" yang diramalkan itu tidak pernah memuaskan hati masyarakat. Kalau pun Kejawen masih menantikan datangnya "Sang Ratu Adil”, itu bersifat abstrak dan tidak menjanjikan kepastiannya. Dan lebih dari itu, "Ratu Adil" yang dinantikan tidak memiliki dimensi ilahi tetapi semata-mata manusiawi. Walau pun konsep itu tetap menyertakan ajaran dan nasehat moral agar manusia tetap "eling lan waspada" atau ingat, sadar dan waspada dalam menjalani kehidupan.

Semoga ekplorasi dan catatan ini bisa menjadikan kita semakin kaya dalam memahami "Kerajaan Allah dan Paradigmanya”. Paradigma Kerajaan Allah nyata begitu kaya dan agung. Karena tidak saja berciri manusiawi tetapi memiliki dimensi Ilahi yang agung dan menjamin kepastian keselamatan pada nantinya bagi yang percaya.

Stepanus Istata Raharjo, S.Th, M.Hum Staf Pengajar/Dosen Kitab Suci di Sekolah Tinggi Pastoral Kateketik (STPK) "Santo Benediktus” Sorong, Papua Barat.

Email:istotopr@gmail.com

\section{CATATAN AKHIR}

1 Hadiwijaya, Tokoh-tokoh Kejawen, Ajaran dan Pengaruhnya, eule book, KPP (Kelompok Penerbit Pinus): Yogyakarta 2010 , hlm. 20.

2 Tema ini diulas oleh Clifford Geerts, dalam bukunya: Religion of Java, London, 1960.

3 Lih. Hadiwijaya, Tokoh-tokoh Kejawen, Ajaran dan Pengaruhnya, Uele Book, KPP (Kelompok Penerbit Pinus): Yogyakarta 2010, hlm. 2.

4 Lih. Ahmad Norma Permata (penyunting), Zaman Edan Ranggawarsita, Jejak: Yogyakarta 2007, hlm.5. 
5 Ronggowarsito IV adalah salah satu pujangga dalam tradisi Jawa yang menulis tentang “Jangka Jayabaya” atau Ramalan Jayabawa mengenai zaman kalabendhu (zaman edan/rusak) dan akan datangnya "jaman keemasan”.

6 Gagasan ini dapat dilihat dalam: Hadiwijaya, Tokoh-tokoh Kejawen, Ajaran dan Pengaruhnya, Eule Book, KPP (Kelompok Penerbit Pinus), Yogyakarta 2010, hlm.87-93.

7 Kata “Kerajaan Allah” muncul lebih dari 150 kali dalam Perjanjian Baru. Namun Mateus menggunakan istilah "Kerajaan Surga”. Bagi masyarakat Yahudi dilarang menyebut nama 'Allah' secara langsung, maka digunakan kata 'surga'.

8 Penjelasan mengenai “Kerajaan Allah” mengambil gagasan dari: Jose Maniparampil, Synoptic Gospels: Reading the Synoptic Gospels, Claretian Publications: India 2004, hlm. 281-285.

9 Lihat. Otto Hentz, SJ: Pengharapan Kristen, Kanisius: Yogyakarta 2005, hlm. 46-50.

10 Bagian ini mengikuti alur gagasan I. Suharyo, Pr, Datanglah Kerajaan-Mu, kehidupan bersama yang lebih Bersaudara dan Adil sebagai salah satu Wujud Kemerdekaan, dalam JB. Banawiratma, SJ dan PJ Suwarno (ed): Teologi Kemerdekaan, Sebuah Tinjauan Kristis, Kanisius, Yogyakarta, 1996, hlm. 119-137

11 Mat 6:10; Luk11:2

12 Tulisan tertua dalam Kitab Suci Perjanjian Baru adalah dalam bentuk surat, yaitu 1-2 Tesalonika. Surat ini ditulis pada tahun $41 \mathrm{M}$. Sedangkan tulisan termuda adalah II Petrus (tahun 120 M).

13 "Ini kami katakan kepadamu dengan firman Tuhan: kita yang hidup, yang masih tinggal sampai kedatangan Tuhan, sekali-kali tidak akan mendahului mereka yang telah meninggal. Sebab pada waktu tanda diberi, yaitu pada waktu penghulu malaikat berseru dan sangkakala Allah berbunyi, maka Tuhan sendiri akan turun dari sorga dan mereka yang mati dalam Kristus akan lebih dahulu bangkit; sesudah itu, kita yang hidup, yang masih tinggal, akan diangkat bersama-sama dengan mereka dalam awan menyongsong Tuhan di angkasa. Demikianlah kita akan selama-lamanya bersama-sama dengan Tuhan” (1 Tes. 4:15-17).

\section{DAFTAR RUJUKAN}

Ahmad Norma Permata (penyunting), 2007, Zaman Edan Ranggawarsita, JEJAK,Yogyakarta.

Bambang Noorsena, 2003, Menyongsong Sang Ratu Adil: Perjumpaan Iman Kristen dengan Kejawen, Andi Offset: Yogyakarta.

Banawiratma, SJ dan P.J. Suwarno (ed), 1996, Teologi Kemerdekaan, Sebuah Tinjauan Lintas Bidang, Kanisius, Yogyakarta

Geertz, Clifford, 1960, Religion of Java, Collier McMillan, London

Hadiwijaya, 2010, Tokoh-tokoh Kejawen: Ajaran dan Pengaruhnya, Eule Book, Yogyakarta.

Maniparampil, Jose, 2004, Synoptic Gospel: Reading the Synoptic Gospels, Claretian Publications, India.

Marwoto, S, 2010, Ramalan Jayabaya, Apa Relevansinya dengan Ramalan Suku Maya, Pustaka Mahardika,Yogyakarta.

Otto Hentz, SJ, 2005, Pengharapan Kristen: Kebebasan, Kerajaan Allah, Akhir Zaman, Kematian, Kebangkitan, Neraka, Pemurnian, Keabadian, Penghakiman, Kanisius, Yogyakarta.

Suharyo, I, 1989, Pengantar Injil Sinoptik, Lembaga Biblika Indonesia, Kanisius,Yogyakarta.

Suyono, Capt., 2007, Dunia Mistik Orang Jawa: Roh, Ritual, Benda Magis, LKIS, Yogyakarta.

${ }^{14}$ Lih juga Mat. 11:2-6: Pada saat di penjara Yohanes mengutus murid-muridnya untuk bertanya kepada Yesus, apakah Engkau yang kami nantikan atau harus menantikan orang lain? Dan Yesus menjawab, katakanlah kepada Yohanes, apa yang kamu lihat: orang lumpuh berjalan, orang buta melihat, orang tuli mendengar dan orang bisu berbicara. Nyata bahwa Kerajaan Allah itu hadir dalam sabda dan karya Yesus. 